\title{
STUDIES ON CHLORINE AND FLUORINE IN EPPAWELA APATITE
}

\author{
R. P. GUNAWARDANE \\ Department of Chemistry, University of Peradeniya, Peradeniya, Sri Lanka.
}

(Date of receipt : 05 December 1986)

(Date of acceptance : 02 April 1987)

\begin{abstract}
Dehalogenation of Eppawela apatite, which is mainly in the form of chlorfluorapatite, has been investigated in the temperature range 900 to $1300^{\circ} \mathrm{C}$. The loss of fluorine is relatively small while much higher loss of chlorine has been observed. There is a linear correlation between the extent of dehalogenation and the available phosphorus content of the products. Presence of moisture enhances the dehalogenation process. Addition of silica facilitates the removal of fluorine much more than chlorine. In the presence of soda ash, retention of fluorine is greater while almost total chlorine content is removed even at $1100^{\circ} \mathrm{C}$. It is evident that chlorfluorapatite first undergoes isomorphous replacement of halogen with hydroxyl groups to form hydroxyfluorapatite which then undergoes decomposition at higher temperatures to yield more soluble phosphates. Mostly chlorine is removed as $\mathrm{HCl}$ while fluorine is evolved as $\mathrm{HF}, \mathrm{SiF}_{4}$ and $\mathrm{H}_{2} \mathrm{SiF}_{6}$.
\end{abstract}

\section{Introduction}

The apatite group of minerals has the general formula, $\mathrm{Ca}_{5}\left(\mathrm{PO}_{4}\right)_{3} \mathrm{X}$, where $\mathrm{X}$ can be usually $\mathrm{F}, \mathrm{Cl}, \mathrm{OH}$ or a mixture of any of these ions. The end members of this family are referred to as fluorapatite, chlorapatite and hydroxyapatite. Fluorapatite ${ }^{2}$ is found to be the most stable form and as such most natural apatites contain more $\mathrm{F}$ than $\mathrm{Cl}$ or $\mathrm{OH}$.

An estimated reserve of about 25-30 million tons of apatite ${ }^{6}$ occurs at Eppawela in the North Central Province of Sri Lanka. It has been reported ${ }^{6}$ that the samples from the "leached zone" of the deposit at Eppawela contain more chlorine than fluorine. Eppawela apatite has an unusual chemical composition: its $\mathrm{Cl}^{-} / \mathrm{F}^{-}$ratio ${ }^{5}$ is close to 1.3. and it contains negligible $\mathrm{OH}^{-}$. In contrast, some workers ${ }^{12}$ have reported the existence of hydroxyapatite in the same deposit.

Available phosphorus content of apatite is low, ${ }^{4}$ making it unsuitable for direct application as a fertilizer to short term crops. It is believed that fluorine plays ${ }^{9}$ an important role in the solubility of apatite minerals. It has been demonstrated ${ }^{13}$ that defluorination of some rock phosphates at high temperature, yields products possessing higher contents of available phosphorus. Furthermore, haloapatites can be considered as a potential source of halogen although it may not be economical to exploit these minerals commercially for halogens.

In the present study, the loss of fluorine and chlorine components in Eppawela apatite at high temperature has been estimated. Furthermore, the 
effect of water, silica and soda ash on dehalogenation has also been investigated in an attempt to postulate a mechanism for the dehalogenation process and to correlate the extent of halogen loss with available phosphorus content of the product.

\section{Experimental}

\subsection{Thermal treatment}

Rock phosphate No. 1 sample (100 mesh) from the "leached zone" at Eppawela, apatite - quartz (100 mesh) mixtures and apatite - soda ash mixtures were heated at temperatures of $700-1300^{\circ} \mathrm{C}$ in muffle furnaces using platinum crucibles. Selected samples were also heated at $1350-$ $1400^{\circ} \mathrm{C}$. After heat treatment the samples were quenched in water and the products were examined by powder X-ray diffraction. Differential thermal analysis (DTA) of the rock samples was carried out using a Mettler TA12 Thermoanalyzer at a heating rate of $10^{\circ} \mathrm{C}$ per minute in air, while thermogravimetric (TG) analysis was performed using a Perkin-Elmer TGS-2 Thermogravimetric Analyzer.

\subsection{Chemical Analysis}

Four different samples labelled 1,2,3 and 4 were. collected from four different hillocks in the "leached zone" at Eppawela. Three determinations for each of the components $\mathrm{F}$, $\mathrm{Cl}$, total $\mathrm{P}_{2} \mathrm{O}_{5}$ and available $\mathrm{P}_{2} \mathrm{O}_{5}$ have been made for these samples and the average values are reported in Table 1.

Table 1. Some analytical data of Eppawela apatite

\begin{tabular}{lrrrr}
\hline & Sample 1 & Sample 2 & Sample 3 & Sample 4 \\
\hline Wt. \% $\mathrm{P}_{2} \mathrm{O}_{5}$ & 38.10 & 39.60 & 34.20 & 37.70 \\
Wt. \% F & 1.70 & 1.03 & 1.34 & 0.78 \\
Wt. \% Cl & 2.20 & 2.41 & 2.33 & 2.11 \\
$2 \%$ Citric acid & & & & 5.4 \\
soluble $\mathrm{P}_{2} \mathrm{O}_{5}$ & 6.3 & 6.1 & 5.4 & 5.9 \\
\hline
\end{tabular}

\subsubsection{Halogen estimation:}

About $50 \mathrm{mg}$ samples were dissolved in $5 \mathrm{M} \mathrm{HCl}$ for $\mathrm{F}^{-}$analysis. Analyses were made using an Orion Model 94-09 fluoride ion electrode ${ }^{3}$ by employing an alkali buffer system. Chloride analyses were made on $25-50 \mathrm{mg}$ samples dissolved in 1:1 $\mathrm{HNO}_{3}$. These were diluted with ethanol and titrated to a potentiometric end-point against standard $0.05 \mathrm{M} \mathrm{AgNO}_{3}$. Two per cent citric acid extracts of some fired samples were also subjected to $\mathrm{F}^{-}$and $\mathrm{Cl}^{-}$analyses by the same procedures. 


\subsubsection{Phosphorus estimation.}

Total phosphorus contents of the samples were determined by extracting the samples with a mixture ${ }^{7}$ of conc. $\mathrm{HNO}_{3}$ followed by $65 \% \mathrm{HClO}_{4}$. Available phosphorus contents (in wt $\% \mathrm{P}_{2} \mathrm{O}_{5}$ ) have been estimated ${ }^{11}$ by the $2 \%$ citric acid method. Approximately $1.0 \mathrm{~g}$ samples of finely powdered (100 mesh) samples were extracted with $100 \mathrm{ml}$ of $2 \%$ citric acid using a mechanical shaker operating at about 250 oscillations per minute for a period of 30 minutes. All the extracts were analysed for phosphorus by the vanadomolybdate $\operatorname{method}^{7}$ using a Unicam SP 600 colorimeter at a wave length of $460 \mathrm{~nm}$.

\section{Results and Discussion}

\subsection{Data on Eppawela apatite}

Results of phosphorus and halogen analysis of four different samples collected from the 'leached zone' at Eppawela are shown in the Table 1. These values are compared with some of the known rock phosphates ${ }^{9}$ from other countries in the Table 2.

Present chemical analysis confirms that Eppawela apatite contains more chlorine than fluorine and hence it is different from most of the known rock phosphates. Its total phosphorus content is high, when compared to other known deposits, which makes this deposit commercially very important. On the other hand, available phosphorus content of Eppawela apatite is found to be the lowest among the phosphate rocks listed in the Table 2.

Table 2. Comparison with foreign phosphate rock samples

\begin{tabular}{llll}
\hline Phosphate rock & Wt. $\% \mathrm{~F}$ & Wt. $\% \mathrm{P}_{2} \mathrm{O}_{5}$ & $\begin{array}{l}2 \% \text { citric acid } \\
\text { soluble } \mathrm{P}_{2} \mathrm{O}_{5}\end{array}$
\end{tabular}

(\% Wt.)

\begin{tabular}{lccr} 
Flprida hard rock & $3.4-4.0$ & $31-36$ & 7.2 \\
Florida land pebble & $3.2-4.1$ & $30-36$ & 6.7 \\
Tennessee brown rock & $2.6-4.1$ & $25-38$ & 6.2 \\
Tennessee blue rock & $3.3-4.0$ & $28-34$ & 6.8 \\
South Carolina rock & $2.2-3.8$ & $16-29$ & 7.8 \\
Curacao, West Indies & $0.3-0.9$ & $38-41$ & 14.6 \\
Morocco & $4.1-4.3$ & $33-35$ & 10.4 \\
Nauru and Ocean Islands & $2.0-3.3$ & $38-41$ & 10.1 \\
Christmas Island & $1.0-1.5$ & 39 & 13.2 \\
Eppawela, Sri Lanka & $0.8-1.7$ & $34-40$ & 5.9 \\
\hline
\end{tabular}

Note: Wt. \% $\mathrm{Cl}$ values for foreign rock samples are not available in the literature. 
Synthetic experiments made using tricalcium phosphate, calcium chloride and calcium fluoride followed by the comparison of powder X-ray diffraction patterns of ratural and synthetic samples confirmed that the Eppawela apatite is in fact a chlorfluorapatite. Its X-ray powder pattern could be indexed using a hexagonal unit cell with $\underline{\mathrm{a}}=9.470(10) \AA$ and $\underline{c}=6.863(5) \AA$. Differential thermal analysis of this sample did not show any thermal transition up to $1000^{\circ} \mathrm{C}$ while thermogravimetric analysis showed a weight loss of $0.6-1.0 \%$ in the temperature range $500-1000^{\circ} \mathrm{C}$. This is mainly due to the loss of halogen as evidenced by the available experimental data. However, the confirmation of identity of the evolved gases by mass spectroscopy was not possible in this study.

\subsection{Dehalogenation}

Halogen loss observed in Eppawela apatite on heat treatment as well as 2\% citric acid solubility of the products are shown in Table 3 . Total loss of halogen (both chlorine and fluorine) after heat treatment in the temperature interval $700-1300^{\circ} \mathrm{C}$ was found to be in the range $6-15 \%$. The loss of fluorine was nearly a constant ( $5-6.5 \%)$ while much higher loss of chlorine $(\sim 7-22 \%$ ) was observed in the same temperature range (Figure 1$)$. When the heating time was increased to 25 hours at $1300^{\circ} \mathrm{C}, 70 \%$ of chlorine was lost while only about $12 \%$ of fluorine was evolved under the same conditions.

Table 3. Halogen loss in Eppawela apatite at high temperature

\begin{tabular}{|c|c|c|c|c|c|c|}
\hline \multirow{2}{*}{$\begin{array}{l}\text { Tempera- } \\
\text { ture }{ }^{\circ} \mathrm{C}\end{array}$} & \multirow{2}{*}{$\begin{array}{l}\text { Time } \\
\text { hrs. }\end{array}$} & \multicolumn{2}{|c|}{ Fluorine } & \multicolumn{2}{|c|}{ Chlorine } & \multirow{2}{*}{$\begin{array}{c}2 \% \text { Citric } \\
\text { acid soluble } \\
\mathrm{P}_{2} \mathrm{O}_{5} \text { (wt. \%) }\end{array}$} \\
\hline & & \% wt. F & $\%$ loss $\mathrm{F}$ & $\% w$ of $\mathrm{Cl}$ & $\%$ loss $\mathrm{Cl}$ & \\
\hline 700 & 2 & 1.62 & 4.7 & 2.04 & 7.3 & 6.5 \\
\hline 900 & 2 & 1.61 & 5.3 & 1.99 & 9.5 & 7.2 \\
\hline 1100 & 2 & 1.60 & 5.9 & 1.96 & 10.9 & 8.8 \\
\hline 1300 & 2 & 1.59 & 6.5 & 1.72 & 21.8 & 10.1 \\
\hline 1300. & 25 & 1.50 & 11.8 & 0.66 & 70.0 & 13.0 \\
\hline
\end{tabular}

Correlation between the available $\mathrm{P}_{2} \mathrm{O}_{5}$ contents and the percentage dehalogenation in Eppawela apatite is shown in Figure 2. It is apparent that there is an increase in the available phosphorus contents with increase in the extent of dehalogenation. It has also been observed that the presence of water enhances dehalogenation. For example, about $50 \%$ increase in dehalogenation was observed when the experiment was repeated in the presence of added water at $1100^{\circ} \mathrm{C}$.

During heat treatment the rock phosphate changed its colour from yellowish white (room temperature) through greenish pink $\left(1100^{\circ} \mathrm{C}\right)$ to green $\left(1300^{\circ} \mathrm{C}\right)$. X-ray powder pattern of the products clearly show that 


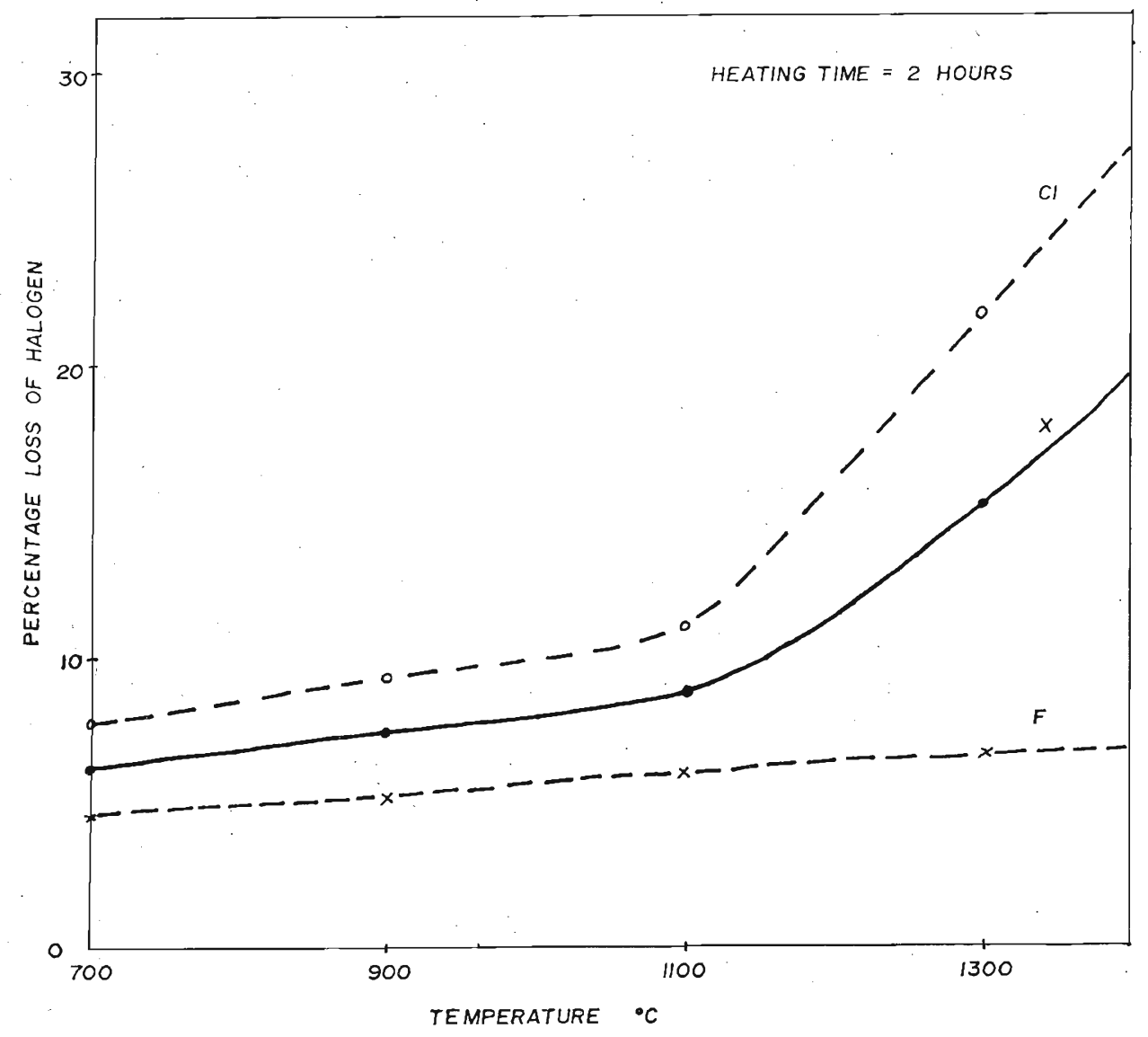

Figure 1. Effect of temperature on dehalogenation of Eppawela apatite. 


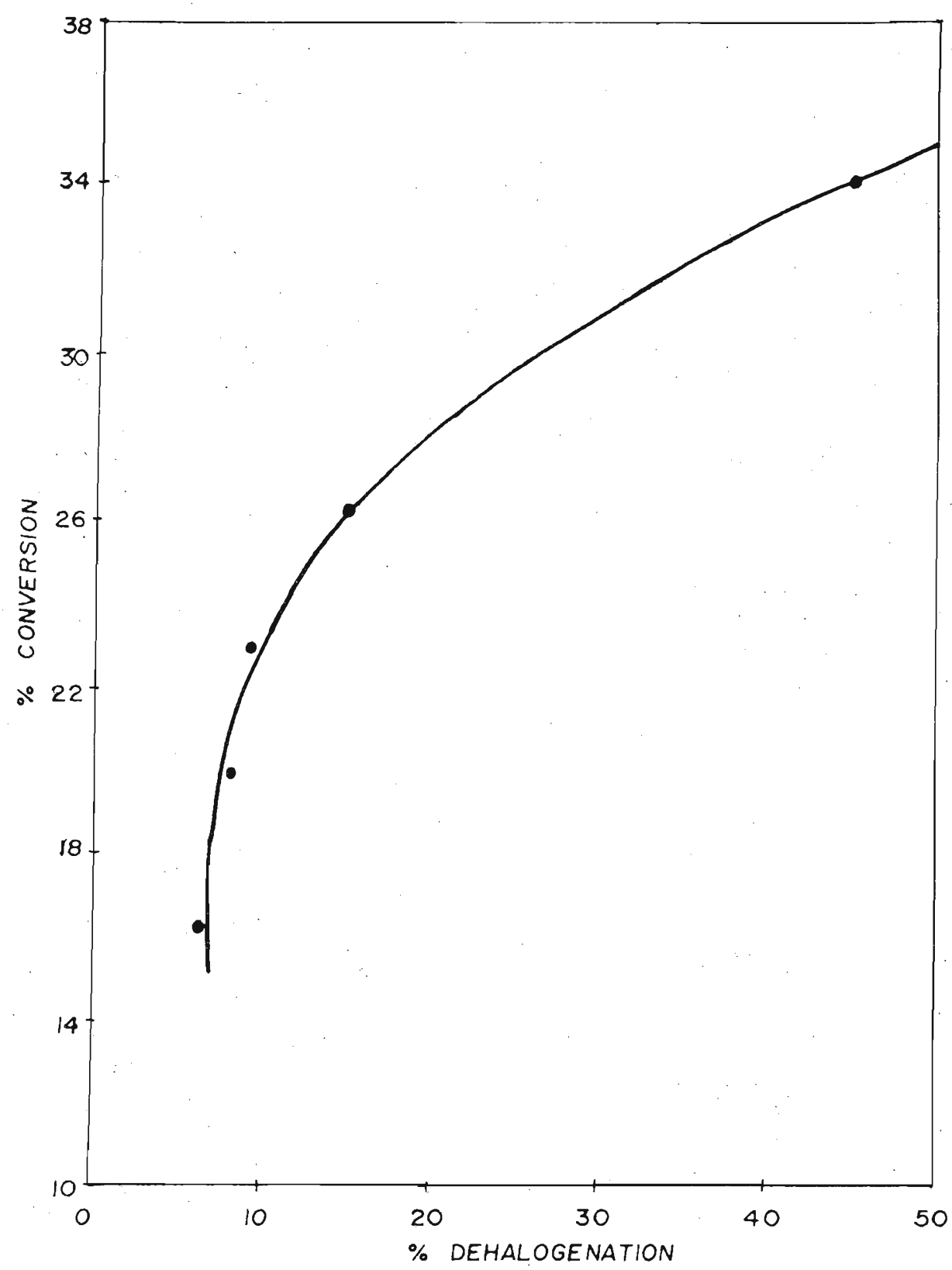

Figure 2. Relationship between dehalogenation and percentage conversion.

$$
\left(\% \text { conversion }=\frac{2 \% \text { citric acid soluble } \mathrm{P}_{2} \mathrm{O}_{5}}{\text { Total } \mathrm{P}_{2} \mathrm{O}_{5}} \times 100\right)
$$


there is a pronounced shift in the powder lines of chlorfluorapatite towards hydroxyfluorapatite. Apatite structure is retained even after 2 hours heat treatment at $1450^{\circ} \mathrm{C}$.

\subsection{Halogen loss in apatite - quartz mixtures}

Loss of chlorine and fluorine in some mixtures containing apatite and quartz at high temperature is presented in Table 4 . It has been observed that there is an increase in the loss of total halogen with rise in temperature (Figure 3). Furthermore, it is evident from the comparison of Figures 1 and 3 that addition of silica facilitates the loss of halogen in the temperature range $900-1300^{\circ} \mathrm{C}$.

Loss of both fluorine and chlorine reaches a maximum and then remains more or loss constant with increase in the amount of quartz added. The maximum loss of halogen was observed at $10 \%$ wt quartz in all the temperatures of the present study. Experimental data (Table 4 and Figure 3) also show that the presence of silica facilitates the removal of fluorine much more than chlorine. The observed chlorine and fluorine losses at $1100^{\circ} \mathrm{C}$ (Figure 3) exemplify this fact. It was also revealed that the addition of water accelerates the removal of halogen from these mixtures as well.

Apatite structure is retained in these compositions at $1100^{\circ} \mathrm{C}$ as shown by powder X-ray diffraction. Product at $1300^{\circ} \mathrm{C}$ was found to contain traces of silicocarnotite and tricalcium phosphate in addition to apatite. Therefore, it appears that the reaction of apatite with quartz is incomplete even at $1300^{\circ} \mathrm{C}$ after 2 hours heating.

\subsection{Halogen loss in apatite - soda ash compositions}

Results are summarised in the Table 5. In general there is a gradual increase of halogen loss with increase in temperature in all compositions with soda ash. With increase in soda ash content there is a greater increase in the loss of chlorine than fluorine. For example, in the compositions containing molar ratios of apatite : soda ash, $2: 3$ and $1: 2$, total chlorine content is lost while only about $32-48 \%$ fluorine is evolved after 2 hours heating at $1300^{\circ} \mathrm{C}$. The major phase in the products was identified as rhenanite, $\mathrm{CaNaPO}_{4}$.

Effect of soda ash on dehalogenation is shown in Figure 4. Loss of total chlorine and fluorine increases with increase in soda ash content up to about. 1.5 mole of soda ash per mole of apatite and beyond this value the effect is negligible. This therefore indicates that the optimum soda ash requirement for the maximum removal of halogen is about 1.5 moles of soda ash per mole of apatite.

It is evident that chlorine removal is greatly facilitated by the presense 


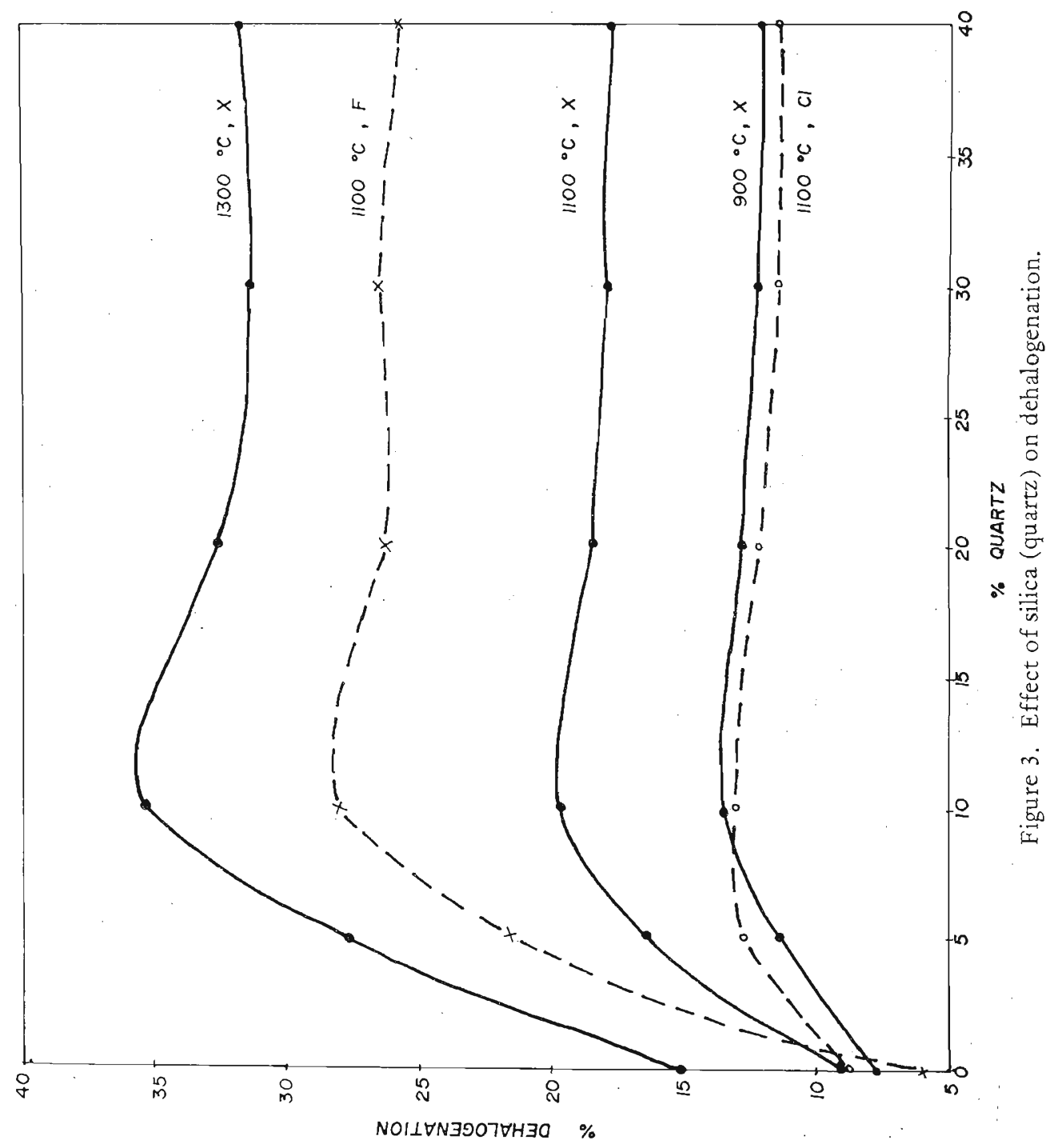




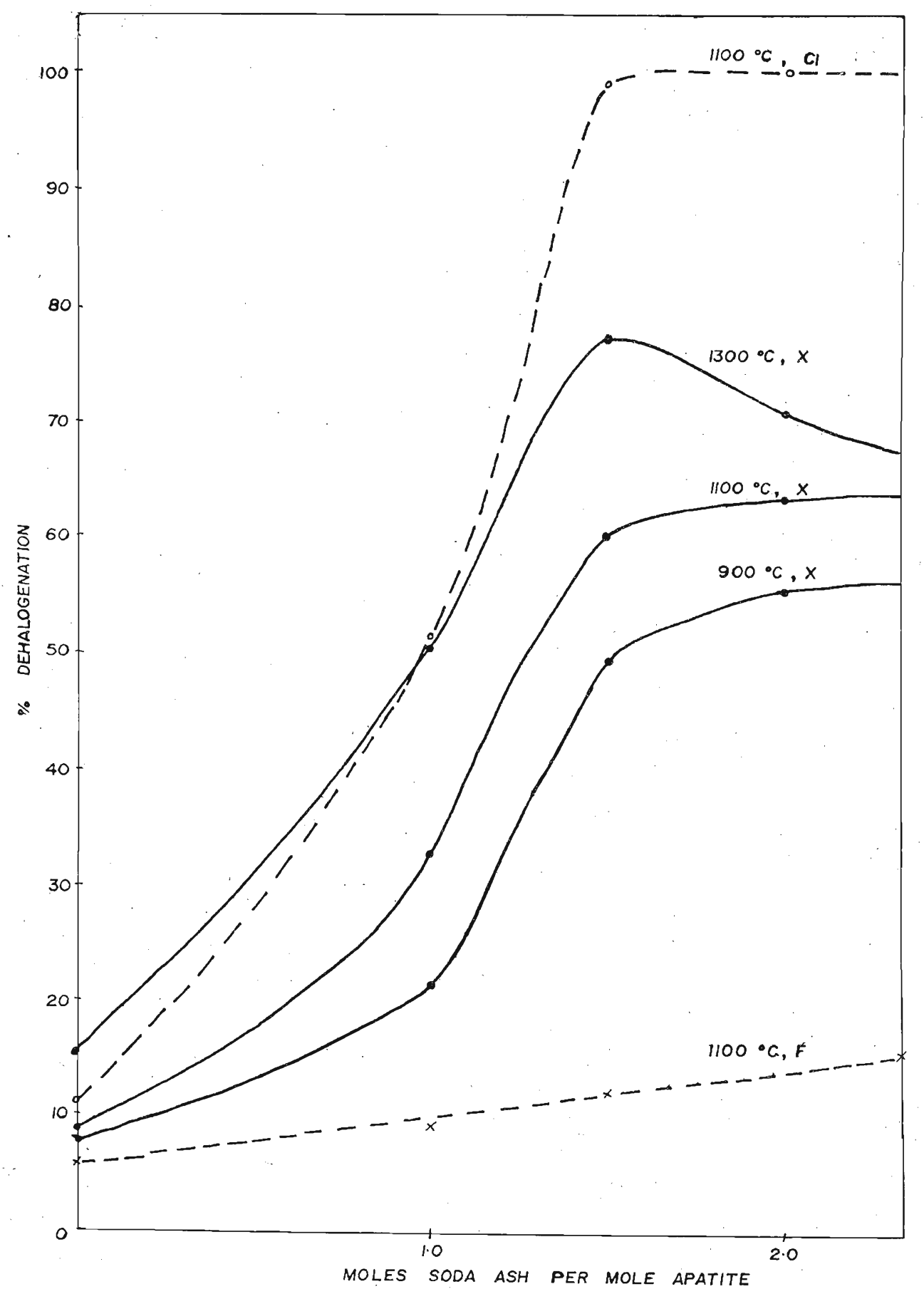

Figure 4. Effect of soda ash on dehalogenation. 

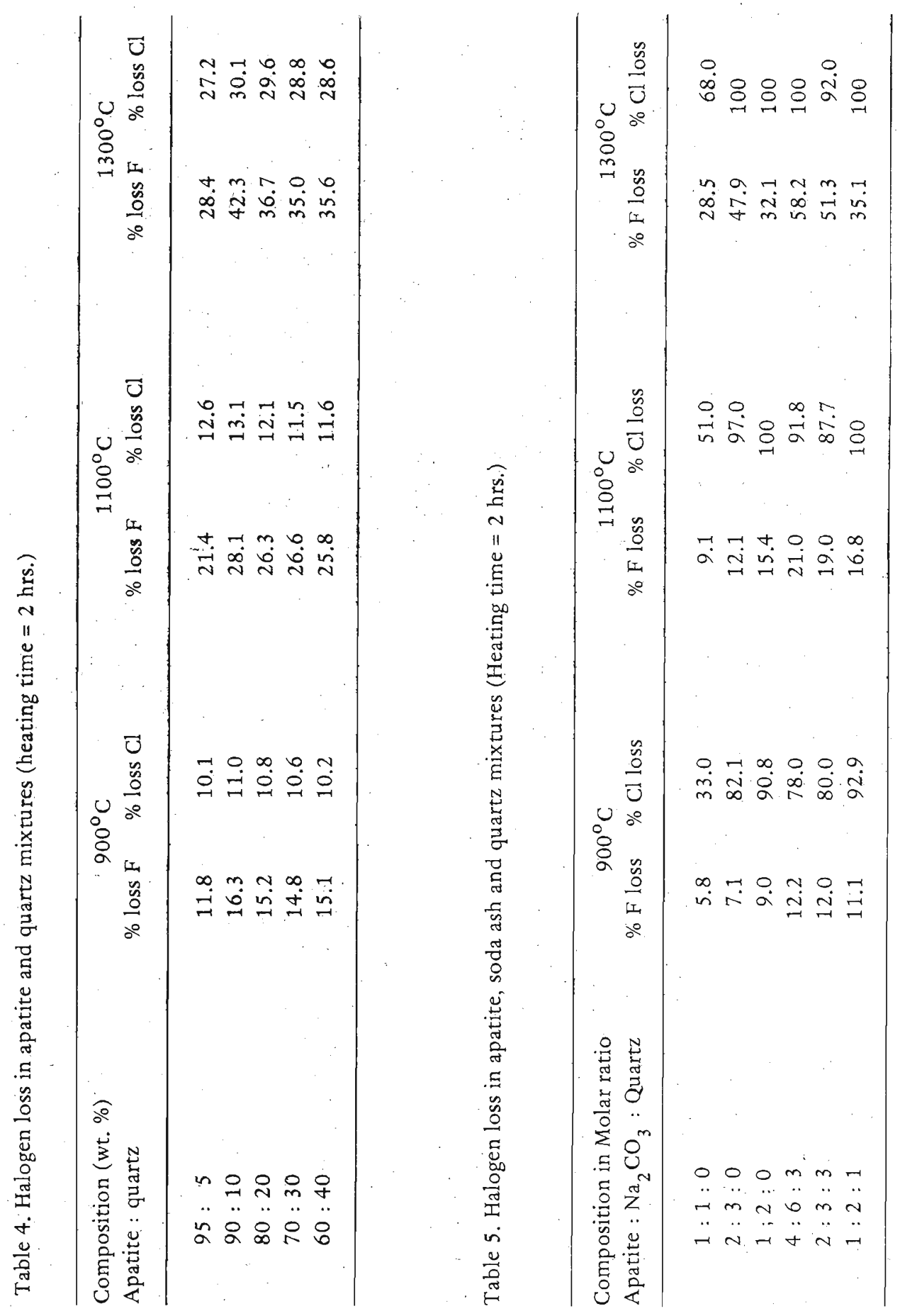
of soda ash. This fact is clearly shown in the fluorine and chlorine components of the halogen loss at $1100^{\circ} \mathrm{C}$ (Figure 4 ). Fluorine loss shows a small but gradual increase with increase in soda content. Loss of chlorine, however, increases rapidly and reaches almost 100\% at 1:1 molar ratio.

Results show that a large proportion of fluorine is retained while most of the chlorine is evolved in the compositions containing soda ash. Therefore, it is of interest to examine the nature of fluorine in these products. No fluorine has been detected in the water extracts of samples fired at $1100^{\circ} \mathrm{C}$ indicating the absence of fluorine in water soluble phases. The products were almost $100 \%$ soluble in $2 \%$ citric acid. Therefore, fluorine should be present in a citric acid soluble phase. However, citric acid extracts were found to contain only a small fraction $(\sim 25 \%)$ of fluorine. As such, the nature of. most of the fluorine $(\sim 75 \%)$ retained in the sintered samples is uncertain. The most plausible explanation would be that the fluorine is present in the form of complex ions such as $\mathrm{SiF}_{6}{ }^{2-}$, fluorphosphates, etc., which are not sensitive to the fluoride ion electrode employed in the present analysis. Thus, values reported in this paper give only the free fluoride ion contents.

\section{Discussion}

Eppawela apatite, which is mainly in the form of chlorfluorapatite, undergoes reaction with moisture in the furnace atmosphere to form hydroxyfluorapatite with the liberation of $\mathrm{HCl}$ and $\mathrm{HF}$. Chlorine liberation in the form of $\mathrm{HCl}$ is facilitated due to the fact that chlorapatite is unstable with respect to fluor- and hydroxyfluorapatite. Hydroxyfluor apatite appears to be stable up to $1400^{\circ} \mathrm{C}$, though no evidence is presented to confirm this.

The structure of apatite has been investigated by $\mathrm{Mehmel}^{8}$ and NaraySzabo. ${ }^{10}$ The vertical chains of calcium and oxygen atoms are linked by $\mathrm{PO}_{4}$ groups to form a honeycomb structure with channels parallel to the $\underline{c}$ axis. The halide ions are positioned within these channels. In fluor- and hydroxyfluorapatites the $\mathrm{OH}$ and $\mathrm{F}$ are situated on mirror planes at $(001 / 4)$ and $(003 / 4)$, whereas in chlorapatite the $\mathrm{Cl}$ atoms are at $(000)$ and $(001 / 2)$. Thus, the positions of halogens in Eppawela apatite (chlorfluorapatite) are uncertain: the tluorine and chlorine atoms cannot all assume their normal positions because the distances between the two sets of sites are not large enough to accommodate halogens at both sites. It is possible that chlorine atoms are forced to occupy fluorine sites in chlorfluorapatites.

Due to steric factors chlorine containing sites are under strain. As such, in the presence of moisture $\mathrm{Cl}$ is replaced by OH with the evolution of $\mathrm{HCl}$. Fluorine may also be lost to a much lesser extent. This also explains the enhanced loss of halogen when extra water is introduced to the furnace. In the presence of silica highly volatile $\mathrm{SiF}_{4}$ and $\mathrm{H}_{2} \mathrm{SiF}_{6}$ would also be formed which accelerates the loss of fluorine. 
Table 6. Solubility data of some phases

\begin{tabular}{|c|c|c|}
\hline Material & $\begin{array}{l}\mathrm{P}_{2} \mathrm{O}_{5} \text { (wt. \%) }\end{array}$ & $\begin{array}{c}\text { Solubility } \\
\text { as a } \% \text { of total } \mathrm{P}_{2} \mathrm{O}_{5}\end{array}$ \\
\hline $\mathrm{Ca}_{5}\left(\mathrm{PO}_{4}\right)_{3}(\mathrm{OH})$ (hydroxyapatite) & 16.2 & 38 \\
\hline$\beta-\mathrm{Ca}{ }_{3}\left(\mathrm{PO}_{4}\right)_{2}$ & 34.0 & 74 \\
\hline$\alpha-\mathrm{Ca}_{3}\left(\mathrm{PO}_{4}\right)_{2}$ & 36.6 & 80 \\
\hline $\mathrm{Ca}_{4} \mathrm{P}_{2} \mathrm{O}_{9}$ & 38.9 & 100 \\
\hline $\mathrm{Ca}_{5}\left(\mathrm{SiO}_{4}\right)\left(\mathrm{PO}_{4}\right)_{2}$ (silicocarnotite) & 30.1 & 100 \\
\hline $\begin{array}{c}\mathrm{Ca}_{7}\left(\mathrm{SiO}_{4}\right)_{2}\left(\mathrm{PO}_{4}\right)_{2} \\
\text { (Nagelschmidtite) }\end{array}$ & 21.9 & 100 \\
\hline $\mathrm{CaNaPO}_{4}$ (Rhenanite) & 45.0 & 100 \\
\hline
\end{tabular}

Available phosphorus content of hydroxyapatite is higher than that in haloapatites. Thus, increase in available phosphorus content with increase in dehalogenation is due to the increase in the extent of the replacement of halogen by 1$) \mathrm{H}$ in the structure. Table 6 gives the available phosphorus values of some phases that may be encountered in the fired products.

Decomposition of chlorfluorapatite on thermal treatment proceeds via two stages.

(a) Isomorphous replacement of chlorine and to a lesser extent fluorine with hydroxyl ions, and

(b) breakdown of the resulting hydroxyfluorapatite to give as the major phases, (i) $\alpha$ and $\beta$ tricalcium phosphate, tetracalcium phosphate, ${ }^{9}$ etc., at $1500-1600^{\circ} \mathrm{C}$; (ii) silicocarnotite and nagelschmidtite in addition to (i), in the presence of silica at $1300-1400^{\circ} \mathrm{C}$; (iii) rhenanite in the presence of soda ash at $900-1300^{\circ} \mathrm{C}$.

\section{Acknowledgement}

The author is grateful to Dr: M. Masson of the University of Aberdeen, U.K. for her assistance in the fluorine analysis and the International Seminar in Chemistry of the Uppsala University in Sweden for financial assistance to perform thermal analysis at the Arrhenius Laboratory, University of Stockholm, Sweden. 


\section{References}

1. BARret, R. L. \& McCAUghey, W. J. (1942) Am. Minerologist, $27: 680$,

2. CORBRIDGE, D. E. C. (1974) The structural chemistry of phosphorus, Elsevier. Publishing Company, Amsterdam, London, New York.

3. EDMOND, C. R. (1969) Anal. Chem. $41(10): 1327-1328$.

4. GUNAWARDANE, R. P. (1982) J. Natn. Sci. Coun. Sri Lanka 10 (2) : $181-194$.

5. GUNAWARDANE, R. P. and GLASSER, F. P. (1979) J. Mater. Sci., $14: 2797-$ 2816.

6. JAYAWARDANA, D. E. De S. (1976) The Eppawela carbonatite complex in . North-west Sri Lanka, Economic Bulletin No. 3, Geological Survey Department, Colombo.

7. JEFFERY, P. G. (1971) Chemical method of rock analysis, Pergamon Press, Oxford.

8. MEHMEL, M. (1930) Z.Krist., $75: 323$.

9. MELLOR, J. W. (1971) Comprehensive treatise on inorganic and theoretical chemistry, Volume 3 - supplement 3 , Longmans, London.

10. NARAY - SZABO, S. (1930) Z.Krist., $75: 387$.

11. PIERRE, W. H. \& NORMAN, A. G. (1953) Soil and fertilizer phosphorus in crop nutrition, Academic Press, London, New York.

12. TAZAKI, K., FYRE, W. S. and DISSANAYAKE, C. B. (1986) Applied Geochemistry, $1: 287-300$.

13. Whitney, W. T. \& HOlliwgSwORTH, C. A. (1949) Ind. Eng. Chem., 41 : $1325-1327$. 